\title{
LOCAL CULTURAL LITERACY AND ITS PROMOTION
}

\author{
Retno Muljani and Emanuel Sunarto \\ Sanata Dharma University, Indonesia \\ retnomuljani@usd.ac.id and esunarto@usd.ac.id \\ DOI: https://doi.org/10.24071/ijhs.2018.020104 \\ Received 26 June 2018; revised 27 July 2018; accepted 3 September 2018
}

\begin{abstract}
This study addressed two research questions: what educational functions can be promoted through Museum Wayang Kekayon (MWK) collections? And what criteria should promotional media have to promote MWK? The study implemented hermeneutic approach supported by theories of Semiotics, Discourse, Pragmatics, and Web Usability. Data were collected by browsing the Internet, conducting observations while visiting MWK, interviewing experts on museum, wayang, and semiotics and MWK educators. The findings of the study were 1) the identification of MWK educational functions to introduce cultural literacy and other relevant philosophical values, and 2) the CLEAR criteria of effective promotional media to promote cultural (wayang) literacy in the digital era. The study recommended that fun but meaningful activities should be conducted at MWK, and relevant resources and tools should be provided and used to support the activities.
\end{abstract}

Keywords: local cultural literacy, museum, promotional media, wayang

\section{Introduction}

Wayang is an artistic cultural masterpiece which has a deep-rooted foundation in Indonesian community. Wayang performances describe complex human life symbols from birth until death (Soetrisno, 2008:3). Philosophy, life wisdom, human characters, moral-social teachings are some aspects related to wayang and its performances that can be sources of interest to researchers. UNESCO's declaration which acknowledged wayang as" A Masterpiece of The Oral and Intangible Heritage of Humanity" on 7 November 2003 confirmed wayang as the world cultural heritage. As a museum (which possesses thousands of wayang collections, Museum Wayang Kekayon Yogyakarta (MWK) could have been a place of interest to visit. However, previous studies indicated that MWK might neither be a must-visit site for tourists coming Yogyakarta nor an object of regular visits by local people. There are some reasons for this phenomenon and previous studies have been conducted to discover strategies to promote MWK and to increase selling points of MWK (Juwita 2014; Purnomo 2016). Considering that the complete research design was multi-year, the researchers decided to focus on the identification of MWK functions to 
introduce cultural literacy, and the adoption of appropriate criteria for MWK web site as a far-reaching promotional medium to promote the cultural literacy which is typical of Indonesia (note: the next stage of the research would be the construction of MWK website based on the discovered criteria as an effective means of promotion). The website should be communicatively informing relevant and reliable information and user friendly.

\section{Museum Wayang Kekayon Yogyakarta (MWK)}

The founding father of MWK is the late wayang collector whose name is Professor Dr. KPH Soejono Prawirohadikusumo - a professor in one faculty of medical study and an expert in Javanese culture. A great collection of Wayang Purwa, Wayang Madya, Wayang Gedhog, Wayang Klithik, Wayang Golek and many other kinds of wayang and masks are stored in MWK. The collection is privately owned by his family. Therefore, MWK may be categorized as a museum of specialized collections, particularly wayang collections (Hein 2005).

In 1990 MWK was officially opened by Sri Paduka Paku Alam VIII - the Vice Governor of Yogyakarta Special Region (DIY) Afterwards, MWK was opened for public fully in 1992 and since then it has joined Badan Musyawarah Museum (Barahmus) DIY. It is located at Yogyakarta-Wonosari street no 277, Banguntapan, Bantul, Yogyakarta.

There are seven (7) units surrounded by a large garden in the museum complex. However, the study only explored Units 1 and 2 in which Wayang Purwa collections were stored and displayed. In Unit 1, visitors could observe a complete set wayang arranged neatly with its essential decorations such as pakeliran, blencong, and artificial dalang sitting facing the pakeliran. On the right side of the dalang were wayang of good characters and knights whereas on the left side were wayang of bad characters. There is also a replica of Gatotkaca - a popular puppet figure who was the son of Wrekodara of the Pandavas. In Unit 2, wayang collections narrating the episodes of Ramayana, Mahabarata, and Karna Tanding were stored. The episodes and figures belong to Wayang Purwa collections - the objects of the study ( source: Panduan Pengunjung Museum Wayang Kekayon Yogyakarta).

Wayang is acknowledged as having tangible and intangible aspects. The tangible aspect refers to the objects of carved leather representing characters. The tangible aspects can be seen, touched, stored physically. The intangible aspects of wayang cannot be seen or touched but they can be taught, shared, delivered through wayang performances. The intangible aspects include wayang performances, Javanese poetry, transfer of dalang skills to next generation (source: an interview with the owner of MWK and a resource person of museum on 18 August 2017). It is both the tangible and intangible aspects of wayang which will be explored further to address the two research questions.

\section{Roles of Museums}

Related to the museum functions as a place for conservation, research, education, and entertainment, a museum can have particular roles in society, namely, education and social action (Hein 2005). Furthermore, he states that "museums are primarily education institutions". They have roles in preserving 
culture and they are open to public. In this way, they become public institutions having certain educational work related to culture. Visitors to museums, especially children, can experience education which is object -based or inquirybased. They can actively learn to solve problems by constructing meaning based on their knowledge acquired previously and the experiences in visiting the museums

In addition, museums can also have social roles such as what happened in the early twentieth century when John Cotton Dana (1856-1929) - the founder of the Newark Museum - initiated progressive education and expanded museum functions to include citizen empowerment leading to a democratic society.

Bearing in mind the two integrated roles of museums and simplifying the roles to meet the present local context, the researchers study MWK's wayang collection and the public service assigned to MWK. The result is the identification of relevant cultural values embedded to certain wayang figures which can help us build, develop, and maintain better community life. Values such as heroism, nationality, honesty, loyalty can be introduced and shared to visitors of MWK

\section{Semiotics}

By referring to Barthes' theory (1956), Susanto states that semiotics is part of linguistics which studies signs in other fields which can be used as a language to express and represent meanings (staff.ui.ac.id/system/files/users /irzanti.../ metode semiotika.pdf). Further, Susanto considers that signs can deliver certain information. Signs can be communicative. Signs can also represent the meanings of other objects or things which can be comprehended by those seeing the signs. Thus, any research implementing semiotic theories is usually "qualitative-interpretive".

Susanto also discusses Charles Sanders Peirce's theory (1839-1914) that signs are representatives which explain something (triadic concept) and a certain sign becomes meaningful because of the context when the sign is used. Meanings can be personal or social depending on certain contexts. Peirce also uses the term representamen as used in the triadic concept, however, he sometimes uses the term sign as well.

In addition, Petrilli's theory on sign and meaning (2015) is also implemented in this study as the underlying semiotic theory. In live communication, meaning can be constructed when a sign is used to signify something by an utterer and understood by the listener. Signs must be interrelated in order to be meaningful. Therefore, signs representing meanings about wayang should be studied in relevant contexts so that they can be used communicatively for MWL promotional media, especially for its website.

\section{Discourse}

The MWK website as the focus of the study has texts and pictures. Ideally, the texts and the pictures should be in harmonious intertextuality. There are four basic text types generally known such as narrative, descriptive, expository, and argumentative. Another classification of text types introduces informative and 
instructive texts. Websites are included in informative texts (www.bbc.co.uk accessed on 6 October 2017). Each text type has its main functions and features but rarely does a text have just one type exclusively.

A particular text can be relatively easy to comprehend or, on the other hand, quite complicated to comprehend. This characteristic is usually known as text readability. According to DuBay (2004), a writer can produce a readable text by 1) using simple words not confusing words, 2) avoiding biases in the language used, 3) employing correct grammar rules, correct punctuation and spelling, accepted graphical elements and markers. In addition, Blakesley (2011) adds five sentence readability principles to be paid attention to by writers. They should pay attention to action style, agent and action position, modifier and modified words position, information arrangement, and characters in agent positions.

The theories on sentence and text readability need to be "crosschecked" by "modifying" the Cooperative Principles of Grice maxims to ensure the quantity, quality, clarity, relevance of information provided at the promotional media, especially MWK websites.

\section{Web Usability}

Quensenbery (2006) proposes the criteria of "Balancing the 5 Es" as part of the theories on Web Usability. They are effective, efficient, engaging, error tolerant, and easy to use. Each will be described as follows.

A website must effectively facilitate its users to reach their purposes. A website must be efficient in the sense that it can work fast and accurately to support users. A website should have an interesting interface so it can engage its visitors and satisfy its users. A website should also be error tolerant that it can prevent errors but it also provides a recovery system. Last but not least, a website must be user friendly so it allows users to access with ease.

To sum up, all of the underlying theories on Semiotics, Discourse, Pragmatics, and Web Usability can be synthesized and adapted to result in a criteria of effective promotional media, especially, a website, for MWK. The criteria can be used to design and build an effective web site which can support MWK' educational roles and functions in general. The figure of the synthesized theoretical framework is provided on the next column. 


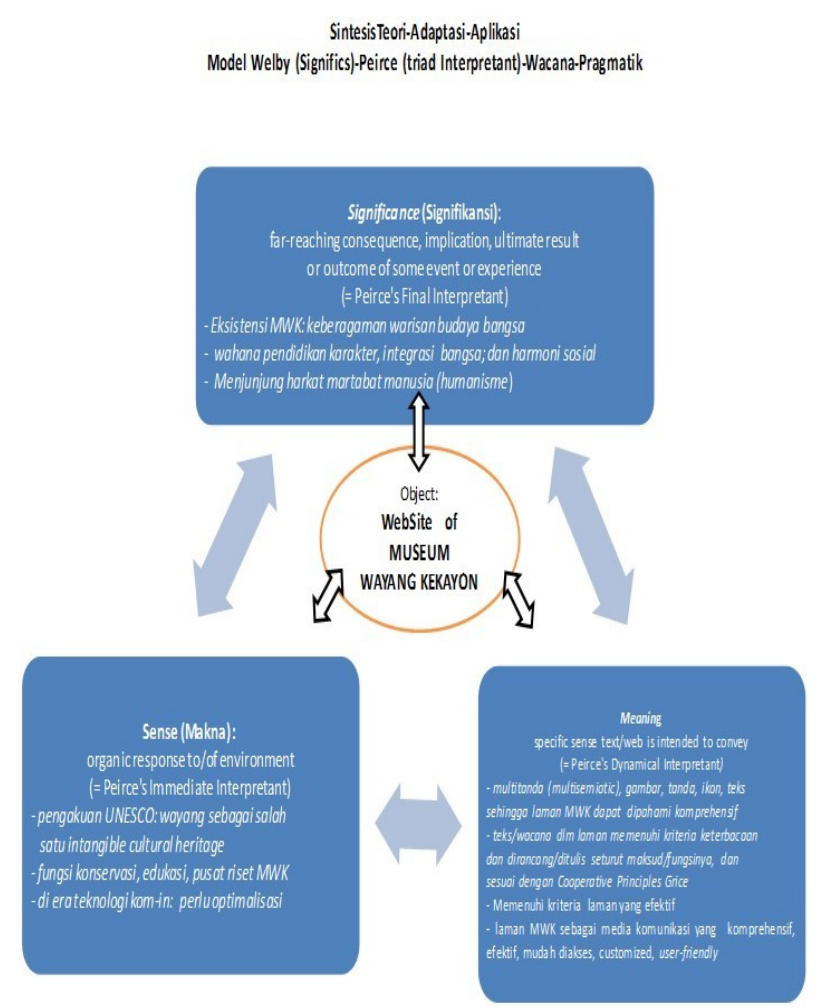

Fig 1: The synthesized and adapted Piere and Welby Theories

\section{Method}

The study was a qualitative descriptive study adopting hermeneutic approach to interpret signs, pictures and texts related to MWK collections in order to construct meanings. As the first year of a multi-year research, the study aimed at 1) identifying educational functions of MWK, and 2) discovering the criteria of MWK effective promotional media, especially the website to promote MWK.

The data of the study consisted of primary data and secondary data. The primary data referred to the tangible and intangible aspects of MWK's wayang collections and the data from the research subjects- resource persons and MWK educators. The secondary data were the data collected by browsing the Internet to search for information about MWK, available websites, blogs, and other promotional media, and elements of good websites.

\section{Research Subjects}

There were three MWK educators and three resource persons involved in this study. Since the nature of the study was "qualitative-interpretive", the researchers selected three resources persons who were experienced in their fields so that they could provide rich data regarding wayang, museums/MWK, and semiotics. Three MWK educators provided data on MWK's wayang collections and special events conducted at MWK. They were interviewed at different dates and places. The schedules were provided in the Data Collection sub-sections. 


\section{Data Collection}

The primary data of the study, namely, the data about MWK collections and events, were collected during three visits to MWK ( the second and third weeks of April and the third week of June 2017) by using commonly used qualitative research instruments: observations, individual interviews, and group discussions (libweb.surrey.ac.uk. skills accessed on 5 Otober 2017) While visiting MWK, the researchers observed all MWK rooms and collections using an observation checklist. The data collected were the identified seven (7) rooms or units in which wayang collections, statues, masks, and paintings were displayed. The researchers also received one brochure of MWK which described some of MWK favorite collections, such as the collections of Pandava and Kaurava wayang, wayang collections from different parts of Nusantara, and adapted wayang figures to match zodiac characters.

A sampling technique was conducted to decide which wayang collections would be the focus of the study. It was Pandava and Kaurava wayang collections out of more than 5500 wayang figures. The popularity of the Pandavas and Kauravas in Mahabharata series and the rich values embedded in the wayang figures and narratives were the reasons of selecting them as the wayang characters to study..

Two other printed brochures were collected in the third visit. One was a "guide sheet" to MWK whereas the other described MWK briefly and mentioned social media belonging to MWK. In the third visit, the sampled wayang collections were re-confirmed.

The online promotional media were collected from January until mid of June 2017. First, a variety of media were identified and scrutinized to result in the sampled far-reaching promotional media, namely MWK website designed by Dinas Kebudayaan Provinsi Daerah Istimewa Yogyakarta.

The first resource person (RP 1) was interviewed twice on 18 and 25 August 2017. He was the owner of MWK and one of the museum board members of Yogyakarta (Badan Musyawarah Museum/BARAHMUS). The data collected from him were related to MWK special collections, vision and mission, values embedded at particular wayang figures and how to relate the values to nowadays life contexts.

The second resource person (RP 2) was a dalang (a puppet master) who was interviewed on 23 September 2017. He was an experienced dalang and his expertise was required to provide expert judgements on what aspects to introduce or share to public, which wayang figures are worth promoting, how to introduce and promote them to young generation, and aspects related to the intangible cultural heritage.

The third resource person (RP 3) was a professor on linguistics and a lecturer of Semiotics who shared his knowledge about signs, symbols, and meanings related to wayang and MWK existing website.

The secondary data were collected through a library study to learn about MWK, to compare and contrast museum websites, and to discover general criteria of good museum websites. 


\section{Data Analysis}

All data collected from the observations, visits to MWK, semi structured interviews, and library study were noted, transcribed and analyzed qualitatively to address two research questions. Coding was created to categorize recurring information and to create themes, for example, NIL = nilai meaning values, $\mathrm{SIM}=$ simbol meaning symbols, $\mathrm{KRT}=$ kriteria meaning criteria, INT $=$ intangible aspects, $\mathrm{KOM}=$ komodifikasi meaning commodification, $\mathrm{PROM}=$ Promosi meaning promotion, $\mathrm{TOK}=$ tokoh meaning figures, and $\mathrm{AKT}=$ aktivitas meaning activities. Some codes were combined such as NIL-INT- RP 1 and RP3 which refer to nilai as intangible aspect stated by resource persons 1 and 3.

The data quality was of paramount importance. Thus, triangulation techniques were implemented. Different ways to collect data were adopted such as observations (three times), interviews (five times with three different resource persons), group discussions. The group discussions were conducted among researchers and a focus group discussion (FGD) with the resource persons and MWK educators was planned to be conducted in the third week of October 2017.

\section{Procedure}

The procedure of the study was as follows: first, reviewing literature and related documents on museums, wayang, and websites; second, formulating the two research questions as the focus of this first -year research; third, collecting both primary and secondary data; fourth, determining data quality through triangulation; fifth, analyzing data; sixth, reporting results.

\section{Findings and Discussion}

The findings related to the first research question about the educational functions of MWK can be divided into two main functions, namely, to introduce, share, and teach cultural local values, and 2) to develop children's passion toward wayang as local culture. The functions were reported as themes.

\section{Theme 1: Loyalty, brotherhood, equality, honesty are reflections of one's character.}

1. Wrekodara who always spoke in bahasa Jawa ngoko implicitly taught us to treat all people as equal partners. (NIL- INT- RP 1)

2. Karno symbolized everlasting brotherhood although he seemed to have betrayed his brothers by taking sides to the Kauravas family. He never betrayed his brothers because if he did not join the Kauravas, the war and situation might be worse for the Pandavas - his brothers by blood. This can be interpreted as a reminder for not judging people too quickly. Also, being loyal as a knight towards his country is heroic. The episode of KARNO TANDING is a popular and favorite episode (NIL-INT- RP 1 and 3)

3. Trijata was known as a loyal companion of Sita - Rama's wife- in her adversity. Trijata always comforted Sita and supported her psychologically when Sita was feeling desperate and worried about her husband. Thus, children/teenagers need to learn to build friendship and maintain it by being loyal to their friends. (NIL-INT-RP1and 3) 


\section{Theme 2: Wisdom and open mindedness are necessary.}

1. All wayang were arranged at a pakeliran in such a way that all wayang of good characters were positioned at the right side of dalang and wayang of bad characters were at the left side. However, dalang could change the positions, for example, when he wanted to deliver certain messages that there was no rigid dichotomy in life, no rigid separation between goodness and badness which he might call as a grey area. Thus, there might be wayang of good characters among the Kauravas as well. (NIL- INT- RP2 and EDU 12 )

2. Local wisdom which is part of cultural heritage needs to be shared and taught to people. It can develop harmony in life, togetherness, etc...so why is it abandoned? (NIL- RP1 and 2)

\section{Theme 3: Dying as a hero for one's country is an honor.}

The episode of KUMBOKARNO GUGUR implies heroism. He was a brother of Ravana who died in a war with the Pandavas not because he wanted to defend Ravana who kidnapped Sinta but because Kumbokarno wanted to defend his country. He criticized Ravana strongly before he went to the battle field and finally he died as a hero. ( NIL-INT- RP 2)

The previously mentioned examples of values embedded to certain wayang figures are part of the intangible aspects of wayang. Using wayang figures to narrate interesting activities and episodes (TOK and AKT) artistically is one of the many ways to introduce, share, and teach educational and philosophical values. This way can also bring children and young people closer to their Indonesian cultural identity.

\section{Theme 4: Becoming a dalang: why not?}

1. Another issue of wayang as a cultural heritage is how to ensure transfer of knowledge, skills, and passions to young people so that they are willing to learn to become dalang. They could start by doing relevant interesting activities. (INT- RP 1 and 2).

2. Children need activities that attract them and once they are attracted they will learn passionately as shared by RP 1 and 2: “ My daughter likes dancing so I encourage and support her and I hope that later she has the passion to learn more about Javanese tembang and wayang, of course." " Other children need competitive activities so kompetisi dalang cilik might be the solution but sponsors must be invited to provide rewards." ( INT- RP 1 and 2)

The findings related to the second research questions concerning the ways to promote cultural literacy are divided into two ways, namely, 1) commodification, and 2) criteria of effective promotional media, especially for MWK website. The two ways are described in themes.

\section{Theme 1: Commodification: is it possible?}

All resource persons state implicitly that commodification, to some extent, is possible and necessary.

1. MWK needed to create fun activities for visitors, for example, providing a kind of selfie booth and other interesting photo backdrops in the museum complex so that visitor could take pictures of their own using their own 
camera phones. This facility may attract more visitors to come to MWK, and the increasing number of visitors can cause positive multiplying effects to MWK and the local community (KOM- PROMRP 1)

2. Adopting contemporary elements in wayang performances was acceptable as far as the modern elements did not "destroy" wayang as a noble heritage of culture. Through this modification, hopefully children and young people would be interested in knowing and learning more about wayang and other forms of local cultural literacy. MWK should provide specific unique souvenirs for its visitors for free or for sale (KOM-RP2 and 3)

Theme 2: Communicative and effective promotional media to introduce, invite, and involve community members in cultural preservation, education, and entertainment will support local cultural literacy, in this case, the knowledge, values, and spirit of wayang collections

1. RP 1 stated that MWK needed websites and also more practical promotional media which could be operated only by using visitors' mobile phones equipped for QR code. Thus, visitors could just come and then found wayang collections they wanted to know more, affixed their cellphones to the barcode to connect with the system and they could get more information about the wayang figure. (KRT-RP 1)

2. MWK website should use relevant signifiers (= penanda). External penanda might be the gate whereas internal penanda is probably the pakeliran. (KRT - RP 3)

3. Prepare engaging and relevant activities which were inquiry-based or problem-based, and promote them via promotional media. Activities could be about figures or relevant events. (KRT-RP 1)

4. Select and use colors and pictures carefully. Use icons and symbols only if their deeper meanings were already understood. (KRT-RP 3)

5. Brief and relevant texts, appropriate letter sizes should be considered in creating captions for wayang collections and other visual descriptions. (KRT-RP 3)

\section{Conclusion}

Museum including MWK should function as educational institutions. As a museum with a quite complete wayang collections, MWK may have the role to introduce wayang literacy as part of local cultural literacy. Values such as heroism, honesty, loyalty, integrity should be part of everyone's daily life which can be introduced, shared, and taught through formal and non-formal educational institutions including MWK and other museums. As a privately owned museum, MWK needs supports such as technology and human resources. Promotional media to inform and invite visitors can be employed, however, they should fulfill certain criteria.

In particular, MWK website should be communicative and user friendly in providing relevant information to public. Visitors who have been interested in visiting MWK need to be exposed to well-maintained collections supported with practical technology and involved in engaging learning activities. 
The educational functions of MWK seem like a big dream to realize. Supports, courage, and good networking can make the dream come true.

\section{References}

Blakesley. 2011. Five principles of sentence readability. Writing center siu. Retrieved from http://write.siu.edu/_common/ documents/handouts/fiveprinciples-of-sentence- readability.pdf. on 22 Mei 2016

Cobley, P. 2010. The routledge companion to semiotics (ed.). London: Routledge. pp. 326-327

DuBay, W. 2004. The principles of readability. Impact information. Costa Mesa: Plain Language Services

Hardwick, C. S. (1977) Semiotic and significs (ed.). The correspondence between Charles S. Peirce and Victoria Lady Welby. Bloomington: Indiana University Press.

Hartono, J. 1999 . Analisis \& disain sistem informasi: Pendekatan terstruktur teori dan praktek aplikasi bisnis. Yogyakarta: Andi Offset.

Hein, G. E. 2005. The role of museum in society: Education and social action. Materials presented at Seminar for Museum Educators 9 Novemebr 2005 in Finland.

Jeffrey, L. W., Lonnie D. B., \& Victor, M. B. 2004. Information system analysis $\&$ design methods $\left(6^{\text {th }}\right.$ ed $)$, Irwin.

Juwita, I. A. E. R. 2014. Strategi pemasaran museum wayang Kekayon Yogyakarta dalam meningkatkan jumlah pengunjung. thesis. https://core.ac.uk/display/38683817/tab/similar-list accessed on 20 September 2017.

Pamungkas Y. W. A., Sriwindono, H., dan Polina, A. M., Sistem informasi museum wayang kekayon Yogyakarta berbasis web. in press.

Purnomo, J. 2016. Disain interior museum wayang Yogyakarta. thesis. https://eprints.uns.ac.id/23539/ accessed on 4 October 2017.

Petrilli, S. 2015. Sign, meaning, and understanding in Victoria Welby and Charles S Pierce. www.journals.uchicago.edu/doi/fu;;/10.1086/679453

Quesenbery, W. 2006. Balancing The 5Es: Usability. http://wqusability.com/articles. accessed on 28 April 2016.

Quesenbery, W. 2006. What Does Usability Mean : Looking Beyond Ease Of Use.http://www.wqusability.com/articles/more-than-ease-of-use.html. accessed on 22 April 2016.

Soetrisno, R. 2008. Wayang sebagai warisan dunia. Surabaya: SIC

Susanto, Irzanti staff.ui.ac.id/system/ files/users/irzanti.../metodesemiotika.pdf accessed on 28 April 2017.

Welby, V. 1977 [1911] 'Significs', in The Encyclopedia Britannica, 11th edn, Vol. XXV. now in C. Hardwick (ed.), Semiotic and Significs. The Correspondence Between Charles S. Peirce and Victoria Lady Welby, Bloomington, IN: Indiana University Press.

www.libweb.surrey.ac.uk accessed on 5 October 2017

www.bbc.co.uk accessed on 6 October 2017 